TO THE END OF THE EARTH: OUR EPIC JOURNEY TO THE NORTH POLE AND THE LEGEND OF PEARY AND HENSON. Tom Avery. 2009. New York: St Martin's Press. 319 p; illustrated; hardcover. ISBN 0-312-55186-X. US\$26.95. doi:10.1017/S0032247409990337

In To the end of the Earth, Tom Avery disavows that his own ability to reach the North Pole in 37 days, the same number Peary reported, 'proves' Peary got there in 1909; it only shows that Peary 'could have done it.' This seems an oddly modest statement, considering the raison d'être of Avery's attempt, and the 'hook' by which he landed his largest sponsor, was his proposal that he would attempt to 'duplicate' Peary's journey using the same methods and means, even going so far as to recreate Peary's wooden dog sled design as the sole means of transport, in an attempt to settle the numerous doubts about Peary's claims. It also does not align with the amount of space Avery devotes in his pages to establishing an evidentiary case designed to show not only that Peary could have done it, but that in fact he did do it, and, conversely, to refuting sceptics who have heaped ridicule on Avery's 'duplicate' journey by detailing all of the ways it differed from Peary's. Avery seems particularly sensitive to the criticisms of his late countryman, Wally Herbert, who reached the North Pole by dog sled in 1969 , and whom he claims to revere, matching him point for point.

The book opens with how the idea for the expedition came whilst casting around for a follow up of his record setting man haul across the Antarctic continent in 2002, with Avery admitting he did not even recognise Peary's name when it first came up in conversation concerning the North Pole. His attempt to demonstrate how much more he has learned of him since is displayed in a brief summary of Peary's whole career. The documented facts of Peary's history are available elsewhere, so perhaps it should just be said that Avery is still no expert on Peary and his expeditions and leave it at that.

In his subsequent description of how he prepared to 'duplicate' Peary's journey, Avery spends much of his time explaining why he did not need to try to duplicate it in most respects, and excusing his use of materials, equipment, and technological devices that were only dreams in 1909 as irrelevant to his goal. One Freudian slip in this section, however, might be agreed to by all those who have doubted that Peary's claimed navigational methods on the way to the Pole, or rather the lack thereof, could have gotten him anywhere near the spot, when Avery avows Peary's method of fixing the Pole was to use 'his sextant and astrological tables.' (page 46)

The bulk of the book is taken up with a day by day narrative of Avery's team's experiences on the Arctic Ocean until its evacuation from the Pole by air. This section of the book brings to mind George Borup's breathless, gee-whiz narrative in his 1911 account of Peary's expedition titled A tenderfoot with Peary. Avery, too, despite his Antarctic experience, presents himself as an innocent abroad: ignorant not only of Peary, but of Arctic exploration history in general; scared silly at the thought of any possible polar bear encounter; with zero experience of sea ice, of driving dogs anywhere, or even of many basics of survival in the Arctic. Though his claims seem disingenuous if only on the strength of his ability to raise vast amounts of capital to fund his attempt, if Avery is truly as he presents himself in his continual disparagement of his abilities, it's understandable why he needed to hire a 'guide,' in the person of Matty McNair, who along with her husband runs an Arctic adventure business in Iqualit. Even so, Avery calls himself the Leader, and did not name his book 'A tenderfoot with Matty.'

Although the book's actual subtitle describes the resultant trek as an 'epic journey,' it is actually rather uneventful and fortunate, as such attempts go: the weather was reasonably good throughout, with only part of day lost to storms; there were no deaths or serious injuries or even a serious mishap; not even a dog died or had to be eaten. But as a comparative expedition to Peary's 1909 attempt, it has as little value as any other attempt to reach the North Pole, including Peary's own failed attempt in 1906, of which his 1909 expedition was in fact a 'duplicate' in all aspects, but with far different claimed results.

Any talk of duplicating or not duplicating Peary's equipment and methods is irrelevant posturing on both sides of the question, though. Even if, like Peary, Avery had been 52 instead of 29 and had lost eight of his toes to frostbite prior to his attempt; even if he had dressed the same as Peary and took exactly the same kind and amount of food, the same number of dogs and assistants, the same number of sledges; even if he had overwintered before setting out, and used only a sextant to find his way, his journey would not have been able to duplicate Peary's. So, all of Avery's critics who have dismissed his journey as proving nothing about Peary's on these grounds are wrong to hold them against him. Peary himself couldn't duplicate Peary. In 1906 the 'Peary system,' which Avery makes much of, failed completely and abjectly, even though Peary bragged it was the only reason why he alone could have succeeded in reaching the Pole three years later.

Although comparative dog sledge journeys have been a favorite exercise in obfuscation since the dispute between Cook and Peary started in September 1909, the truth is that any expedition to the North Pole by dog sled is unique because it is subject to aspects that can never be duplicated or controlled that completely dwarf all nit-picks of technique and equipment that could be mentioned. Those are the prime movers of the Arctic Ocean: the drift of the pack ice due to winds and tides and the variance in spring ice conditions between one year and the next as a result of the previous winter's weather. It is also well known that by about 1920, the local climate began to moderate considerably in the Arctic, well before the conditions now attributed to global warming.

What should be criticised about Avery's journey are not those things that he did not duplicate or which would be unreasonable to expect him to duplicate, but those that always remain the same that he should have taken care not to change. Chief among these was his start time. Peary left Cape Columbia on Ellesmere Island on 1 March 1909, and already, his pioneering parties had been on the trail two days. Avery left Cape Columbia on 20 March 2005, nineteen days later than Peary. This difference in start dates is huge in its consequences. Whether in 1909 or 2005, the sun's position relative to the earth is the same on the same day, always. The difference in usable light available between 1 March and 20 March is really enormous. Significantly, Avery's delay from his planned start date (although he never planned to start on 1 March) was due to his pilot's unwillingness to fly in to Resolute in low light conditions. Collaterally, the temperature is on average significantly lower, and this time of the polar year is noted for fierce equinoctial storms that accompany the polar sunrise. By leaving 19 days later than Peary, Avery gave himself a huge advantage that he should be called to task for. A departure date of 1 March would 
have made making progress in the backbreaking work it takes to clear the mountainous jumble of pack ice crushed against the coast, keeping a reasonably accurate course (a sextant would be positively useless), or even managing such little but time consuming tasks as untangling dog sledge lines just all that much more difficult in the diminished light and elevated cold that took a major toll on Peary's equipment and dogs early in his attempt. There is really no excuse for Avery not duplicating this crucial and never changing aspect of Peary's experiences, since it was one of the few he could truly duplicate. Avery did not have to leave under such onerous conditions, however. Unlike Peary, who had to be off at the earliest possible moment to give himself the best chance of returning before the land-adhering ice went out for the season and left him dangling offshore, as it had, almost fatally, in 1906, Avery had a choice. He just had to reach the Pole in any 37 days to meet his goal, not the same 37 calendar days Peary claimed to travel there. This one factor, alone, invalidates any comparison of the two expeditions. With this not done, the rest of Avery's arguments are moot.

Moreover, Avery addresses the repeated and serious criticism that he made only 'half Peary's journey' by being evacuated from the Pole by saying that he simply could not duplicate Peary's return journey because of global warming, and presents as evidence the fact that the ice began to disintegrate soon after he was carried off the Pole in his rented Twin Otter. However, according to his narrative, Avery's party experienced exceptionally good ice conditions approaching the Pole, which they reached on 27 April, on their 37th day out, a few hours faster than Peary reported. Had they left on the same calendar day as Peary and taken the same time to the Pole, they would have arrived on the same day he claimed, 6 April. Had they done that, Avery would have had no difficulties due to unstable ice in attempting to 'duplicate' what was actually the first of the two most controversial of Peary's claimed feats of speed: NOT reaching the Pole in 37 days, but traveling 133 nautical miles to the Pole, spending a day there, and traveling 133 miles back to that same position in a mere 8 days. And, in fact, since Peary claimed to have returned to his starting point of Cape Columbia on 23 April, and Avery reached the Pole on 27 April, given the ice conditions he reports, had he started on 1 March, Avery should have had a reasonable chance to duplicate Peary's entire journey with several days to spare. Had he done this he could have tested Peary's second most dubious claim: that he traveled the balance of the distance from the Pole in only 14 days. In doing so, Peary more than doubled the speed of his entire outward journey without the advantages Avery makes so much of as to why Peary could reach the Pole so fast: having advance parties to break trail and save his strength, and not having to carry everything he needed on his own sleds to survive the entire distance. Yet it is exactly when those advantages are taken away that Peary records his fastest speeds. As to Avery's discounting of the psychological effects of having to face the other half of the trip Peary had to make, Avery avers early in the book that 'by the time [the expedition] was all over we would be physical and emotional wrecks.' How would they have felt, then, if upon reaching the Pole in 37 days they had to face the whole distance back in a literal race against death, as Peary had to do, and moreover had to do it in just 17 days with only what they had on their sleds upon their arrival at the Pole, with no additional resupplies whatsoever?

Of all the criticisms that have been made of their actual comparative journeys, probably the most valid is that Avery traveled on days when Peary was held up by open water or bad weather. In 1909, he was five days camped by a 'Big Lead' of open water because he had no means to cross it. Avery encountered no comparable delay anywhere on his journey. To be a valid comparison, Avery should have not only left on the same day as Peary, but also should not have traveled on the days Peary didn't travel, 'duplicating' the unique delays be experienced, or, fairer yet, by traveling straight through and then adjusting the amount of time their delays differed at the end. Using that generous formula, Peary only traveled 30 days. Avery traveled 36. Each reported reaching the Pole in 37 days. So, Avery actually took 6 days longer, even given his much more advantageous start time.

As with Avery's summary of Peary's career early in the book, his account of the rest of his book's subtitle, the curiously appropriate 'Legend of Peary and Henson,' it would be a tedious exercise to point out all of the errors and inaccuracies it contains or repeats. His arguments that Peary succeeded in reaching the Pole even if his own expedition did not prove it, are simply that, and do not add anything new to the long list already advanced by others. However, some of his arguments are based on his faulty facts. So, let just one example suffice to show that Avery's notions are not based in documentable evidence, but are his own interpretations drawn, sometimes inaccurately, from secondary sources, particular Herbert's The noose of laurels.

Avery states that 'throughout his expedition career, not once did Peary deliberately set out to exaggerate his achievements or claim to have accomplished something he hadn't' (page 293). On the contrary, the personal papers of Robert E. Peary preserved at the US National Archives II show just the opposite. They are replete with evidence that all of his expeditions before 1909 had produced knowingly exaggerated or false claims. Peary's papers occupy in excess of 225 cubic feet. He kept everything from 25 cent receipts for thermos bottles to memos of his secret thoughts, everything except those things that told the truth about things he had lied about publicly. When he returned from his first Greenland Expedition, he claimed to have proved the insularity of Greenland, but he knew better. His diary entry for 5 July 1891, records his disappointment at his 'puny discovery' of a Greenland fjord instead of the 'North Cape' or the 'East Greenland Sea' that he actually reported survives only in a heavily crossed out stenographer's typescript; the original diary page is nowhere to be found. The crucial pages of his diary documenting his 'Farthest North' of 1906 apparently do not exist at all, in any form. If they did, they might explain why he was able, as he was to do in his 1909 polar claim, to dramatically increase his speed after he had left his last literate witness behind and thus just barely beat the standing Italian record before turning back. His claim of discovering Crocker Land, since proved not to exist, is written off by Avery as a simple mistake attributed to mirage. But not one of the notes Peary left in his cairns at the places he later said he saw it mention its sighting. Instead, one says explicitly 'no land visible.' Peary first mentioned 'Crocker Land' in 1907, when he hoped to coax $\$ 50,000$ from a rich San Francisco banker as a reward for naming 'the most northerly rocks on earth' for him. And the pages of his 1909 diary are blank for the days he claimed to have been at the North Pole. After 17 years of trying to attain the place he confessed to be his life's ambition, he had not one word to say of it once he reached it. Past veracity is no small matter when trying to judge the merits of an explorer's unwitnessed assertion, such as reaching the North Pole with no navigationally competent witnesses. (Avery believes one of the many 'legends' about Matt Henson: that he could make 
celestial observations. All evidence indicates that Henson was barely literate. And in a 1909 letter to his patron, Thomas H. Hubbard, Peary stated categorically that Henson could not take astronomical observations.) Moreover, one cannot be impressed with the authority of Avery's demonstration of how easy it would be for Peary to navigate a true course north when he states as a fact that, "because the sun completes a full 360-degree circle of the earth in one twenty-four-hour day, one degree of longitude equates to four minutes' time' (page 289).

So Avery is right and wrong: his trip does not prove Peary reached the pole nor even that Peary could have reached the pole in 37 days in 1909. It does prove that Tom Avery's party, as equipped and resupplied, reached the North Pole in 37 days in 2005, however. And it shows that just as in Peary's time, big money can be coaxed from rich sponsors if they see some advantage in providing it. Avery did not attach Barclays
Capital and all his numerous other corporate sponsors' names to newly discovered or invented headlands on the Arctic Ocean as Peary did to guarantee their immortality, but he does splash them liberally across his pages, like the branding done in contemporary movies, to increase their exposure.

Peary once said that discovering the North Pole would make him the equal of Columbus and Napoleon. And the reactions of Avery's explorer-critics to his success in reaching the North Pole in 37 days, something Wally Herbert said beforehand was 'impossible,' and Avery's retorts suggest that one thing, at least, hasn't changed in a hundred years: the egos of explorers and adventurers and their overestimation of the importance of what they have actually done or claimed to have done are still as big as they were a century ago. (Robert M. Bryce, Montgomery College, 20200 Observation Drive, Germantown, Maryland 20876, USA.)
SMITHSONIAN AT THE POLES: CONTRIBUTIONS TO INTERNATIONAL POLAR YEAR SCIENCE. Igor Krupnik, Michael A. Lang, and Scott E. Miller (Editors). 2009. Washington DC: Smithsonian Institution Scholarly Press. xv + 405 p. illustrated, paper cover. ISBN 978-0-9788460-1-5. Free on request to Ms. Ginger Strader, Manager (straderg@si.edu). doi:10.1017/S0032247409990349

This volume represents the Proceedings of the 'Smithsonian at the Poles Symposium,' held at the Smithsonian Institution on 3-4 May 2007, and is published as a contribution to the International Polar Year (IPY) 2007-2008. The symposium was a joint initiative of the International Council for Science (ICSU) and the World Meteorological Organization (WMO). An objective of the symposium was to increase understanding of how polar regions affect the habitability of our planet.

Multidisciplinary research from the IPY already provides new evidence of the widespread effects of global warming in the polar regions. Snow and ice are declining in both, affecting human livelihoods as well as local plant and animal life in the Arctic, as well as global ocean and atmospheric circulation and sea level. The chapters in this volume address many of those concerns and more, as our planet experiences changes that will eventually affect humans as well as its fauna and flora.

The 31 chapters by 79 authors represent research associated with Smithsonian initiatives, although the numerous co-authors from other affiliations show wide involvement on a variety of subjects. The chapters are grouped into six themes IPY histories and legacies; cultural studies; systematics and biology of polar organisms; methods and techniques of under-ice research; environmental change and polar marine ecosystems; and polar astronomy: observational cosmology. Multi-authored chapters are particularly prominent in the latter 4 groups, where affiliations range from a variety of U.S. and non-U.S. academic institutions and research centres, the Smithsonian Institution, and native populations in Greenland and Nunavut. Along with authors' names commonly seen in the literature associated with products of their research (Gerald Kooyman, Scripps, diving physiology of emperor penguins and Weddell seals, as only one example), it is gratifying to see native names as co-authors as well, indicating their involvement in the research. Examples are seen in a chapter on narwhal dentition, the 15 authors have affiliations from the Smithsonian as well as names of elders and hunters from Nunavut and Greenland.

Most of the illustrations and maps are in black and white, with some on glossy paper in colour to enhance the resolution and readability of the data. An 11 page index helps the reader locate significant topics in the various chapters. Smithsonian should be commended for making the book available at no cost, thus widening the audience for a significant series of subjects related to the IPY. (John Splettstoesser, P.O Box 515, Waconia, Minnesota U.S.A. 55387.)

\section{ANTARCTIC PILOT: COMPRISING THE COASTS OF ANTARCTICA AND ALL ISLANDS SOUTH OF THE USUAL ROUTE OF VESSELS. S.J. Lawrence (compiler). 2009. Taunton: United Kingdom Hydrographic Office. 7th edition. xviii +489 p., illustrated, hard cover. ISBN: 978-0-70- 774-2014. £50.10.}

doi:10.1017/S0032247409990465

The very subtitle of this latest edition of the Antarctic Pilot referring to 'all islands south of the usual route of vessels' is likely to engender a quickening of the pulse in the reader even before perusal of the volume starts. One has long suspected that deep in the bowels of the Hydrographic Office in Taunton there exists some person, who perhaps rarely sees the light of day, whose task it is to insert in these ostensibly most functional and prosaic of books an element of poetry, a desire to bid farewell to normal cares and to embark on a voyage ... it matters little where. A much more distinguished writer than the present reviewer made a similar point. Somerset Maugham at the start of his famous story The vessel of wrath, written in 1931, enlarges on the merits of the series of works of which the Antarctic Pilot is representative. 'There are few books in the world that contain more meat than the Sailing Directions published by the Hydrographic Department....' $\mathrm{He}$ devotes more than a page of the story to a description 